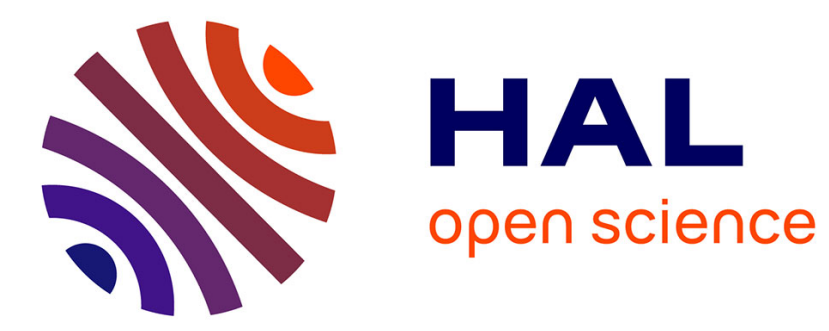

\title{
High temperature behaviour of polypropylene fibres reinforced mortars
}

Mohammed Ezziane, Tahar Kadri, Laurent Molez, Raoul Jauberthie, Ali Belhacen

\section{To cite this version:}

Mohammed Ezziane, Tahar Kadri, Laurent Molez, Raoul Jauberthie, Ali Belhacen. High temperature behaviour of polypropylene fibres reinforced mortars. Fire Safety Journal, 2015, 71, pp.324-331. 10.1016/j.firesaf.2014.11.022 . hal-01096150

\section{HAL Id: hal-01096150 \\ https://hal.science/hal-01096150}

Submitted on 17 Sep 2015

HAL is a multi-disciplinary open access archive for the deposit and dissemination of scientific research documents, whether they are published or not. The documents may come from teaching and research institutions in France or abroad, or from public or private research centers.
L'archive ouverte pluridisciplinaire HAL, est destinée au dépôt et à la diffusion de documents scientifiques de niveau recherche, publiés ou non, émanant des établissements d'enseignement et de recherche français ou étrangers, des laboratoires publics ou privés. 


\section{High temperature behaviour of polypropylene fibres reinforced mortars}

3 Ezziane Mohammed ${ }^{1,2}$, Kadri $\operatorname{Tahar}^{1}$, Molez Laurent ${ }^{2,3}$, Jauberthie Raoul ${ }^{2,3}$, Belhacen Ali $^{1}$

4

5 Affiliations:

6 1. Department of Civil Engineering \& Architecture, Laboratory LMPC, University of Mostaganem727000 , Algeria.

8 2. Laboratoire de Génie Civil et de Génie Mécanique (LGCGM) - EA 3913, Institut National des

9 Sciences Appliquées, 20 avenue des buttes de Coësmes, CS 70839, 35508 Rennes cedex 7, France.

$103 . \quad$ Université Européenne de Bretagne, France

12 Abstract

13 The aim of this paper is primarily experimental and is intended to analyse the behaviour of two 14 cementitious materials, before and after heat treatment: one unreinforced (i.e. without fibres) and the 15 other reinforced (with polypropylene fibres).

16 At room temperature and after heating up to $500^{\circ} \mathrm{C}$, the bending strength is improved by the presences of 17 fibres. The residual young modulus is slightly higher for the fibres reinforced samples.

18 As the temperature increases, the strength gain due to fibres inclusion is reduced. Beyond $500^{\circ} \mathrm{C}$, the 19 bending strength is lower for the fibre reinforced cementitious material compared to those without fibres.

20 Fracture energy is also improved for the fibre mortars at room temperature. At $400^{\circ} \mathrm{C}$ this improvement 21 decreases gradually with the introduction of polypropylene fibres. Beyond this temperature and due to the 22 introduction of polypropylene fibres, the fracture energy is reduced.

23 Another test is developed: rapid heating due to exposure to a flame. The temperature in the front side 24 reaches in few seconds $1000^{\circ} \mathrm{C}$. At this temperature and after one hour of exposure, the opposite side 
25 reached $140^{\circ} \mathrm{C}$. After cooling, the punching shear strength of the fibre mortar is definitely weaker than of 26 the mortar without fibre.

27

\section{KEYWORDS}

29 Polypropylene fibre mortar, Mechanical behaviour, Fracture energy, Fire test, Spalling, Punching shear 30 test

31

32

Corresponding author:

33

Laurent MOLEZ

34

Institut National des Sciences Appliquées, LGCGM

35

Rennes, France

36

E-mail: Laurent.Molez@insa-rennes.fr

37

38 
40 The polypropylene fibres are used in the mortars and concrete to decrease the plastic shrinkage, cracking and micro-cracking of surface [1]. They increase cohesion and reduce slump [2]. While inclusion of metal fibres improves the fire resistance [3], the presence of polypropylene fibres in the material does not [4]. Only the effect limiting spalling at high temperatures is about to be unanimously recognized. This action is primarily studied in high performance concrete i.e. with low water/cement ratio [4-6]. However, during a fire, very strong thermal gradients take place in first centimetres of concrete and the thermal damage rapidly decreases from a maximum to nil $[7,8]$. So, in these first centimetres, where temperatures are less than a critical temperature, polypropylene fibres should still have an effect on mechanical behaviour. The objective of this work is then to examine the effect of the temperature on the residual behaviour of the polypropylene fibre mortars. In addition to the classical flexural strength, we focus to the cracking behaviour and more particularly to the fracture energy and to the stress intensity factor. These characteristics are important in connection with the crack resistance and in particular with the resistance to spalling.

In this paper two type of heating were studied: low rate heating $\left(2^{\circ} \mathrm{C} / \mathrm{min}\right)$ and high rate heating (rate similar to ISO 834 standard fire). These two studies allow to separate physicochemical effects and temperature gradient effect.

\section{MATERIALS}

58 To ensure an effective bridging of the cracks (to limit the crack opening), the dimension of the selected fibres must be greater than those of the aggregates [4]. At room temperature, the aim of the polypropylene

60 fibres in the composite matrix is to ensure a macro cracking bridging and to maintain high post peak strength at a very large crack [9]. In this study cementitious mortars were studied, and then, $12 \mathrm{~mm}$ 
62 monofilament polypropylene fibres were chosen. Characteristics of the fibres (given supplier: SIKA) are 63 detailed in table 1.

64

Table 1: Characteristics of test fibres (given SIKA)

\begin{tabular}{lccccccc}
\hline \multirow{2}{*}{ Fibre } & Length & Diameter & Ratio & Density & Young & Melting & Tensile \\
& $\mathrm{L}(\mathrm{mm})$ & $\varnothing(\mu \mathrm{m})$ & $\mathrm{L} / \varnothing$ & $\rho\left(\mathrm{kg} / \mathrm{m}^{3}\right)$ & Modulus & point & strength \\
& & & & & $\mathrm{E}(\mathrm{GPa})$ & $\left({ }^{\circ} \mathrm{C}\right)$ & $\sigma(\mathrm{GPa})$ \\
\hline Polypropylene & 12 & 18 & 667 & 910 & 6 & 170 & 0,55 \\
\hline
\end{tabular}

66

67 A Portland cement is used: CEM1 52,5 N CE CP2 NF. This cement is made up mainly of clinker 95\%,

68 whose details of the chemical and mineralogical compositions are reported in table 2.

69 The mortars are made with standardized sand according to CEN 196-1 standard with the ISO 679. The

70 mass proportions of cement, sand and water are 1:3:0.5. The volume proportion of added fibres in the

71 fibre mortars is $0.58 \%$ (i.e. $5.2 \mathrm{~kg} / \mathrm{m}^{3}$ ). Water was added to cement and mixed to obtain a homogeneous

72 paste; sand then gradually added to the paste and mixed until homogeneous. Fibres were added at the

73 final stage and dispersed manually. The constituents were mixed for two minutes after the introduction of

74 the fibres.

75 The specimens were then stored in a wet room $\left(20^{\circ} \mathrm{C}, 95 \% \mathrm{RH}\right)$ for 7 days and then stored in dry room

$76\left(20^{\circ} \mathrm{C}, 50 \% \mathrm{RH}\right)$ up to an age of 28 days. Under these conditions, a significant portion of free water in the

77 cement matrix had evaporated [10].

78 
Table 2: Chemical and mineralogical composition of cement CEM I 52,5.

\begin{tabular}{|c|c|c|c|c|c|c|c|c|c|c|c|}
\hline Elements & $\mathrm{SiO}_{2}$ & $\mathrm{Al}_{2} \mathrm{O}_{3}$ & $\mathrm{Fe}_{2} \mathrm{O}_{3}$ & $\mathrm{CaO}$ & $\mathrm{MgO}$ & $\mathrm{K}_{2} \mathrm{O}$ & $\mathrm{NaO}_{2}$ & $\mathrm{SO}_{3}$ & IR & LOI & Free $\mathrm{CaO}$ \\
\hline$\%$ & 22.40 & 2.96 & 2.33 & 66.60 & 0.95 & 0.15 & 0.10 & 2.13 & 0.20 & 1.59 & 0.50 \\
\hline & \multicolumn{3}{|c|}{$\mathrm{C}_{3} \mathrm{~S}=65.3$} & \multicolumn{2}{|c|}{$\mathrm{C}_{2} \mathrm{~S}=18.6$} & \multicolumn{2}{|c|}{$\mathrm{C}_{3} \mathrm{~A}=4.35$} & \multicolumn{3}{|c|}{$\mathrm{C}_{4} \mathrm{AF}=7.14$} & \\
\hline
\end{tabular}

IR : insoluble residue; LOI : loss on ignition.

\section{SLOW HEATING}

\section{3.1. Heat exposure in an oven}

85 Samples, $4 \times 4 \times 16 \mathrm{~cm}^{3}$, were heated in an electric furnace to the desired temperature at a rate of $2{ }^{\circ} \mathrm{C} / \mathrm{min}$.

86 The exposure temperature was maintained during one hour (1h) and cooling to room temperature was

87 carried out in the closed and disconnected furnace (approximately $-0.3^{\circ} \mathrm{C} / \mathrm{min}$ ). The controlled

88 temperature is measured in oven chamber (i.e. not in samples). This process conducts to low thermal

89 gradients. The damages in mortar are mainly of physicochemical origin [11].

90 3.2. Flexural strength

91 After cooling, samples were then tested in a four-point bending configuration. Six specimens were tested

92 for each condition (mortar type and heating temperature). The load is measure with a $50 \mathrm{kN}$ load cell. A

93 template is attached to the specimen to measure deflection using two LVDTs (+/- 1mm) (figure 1). 


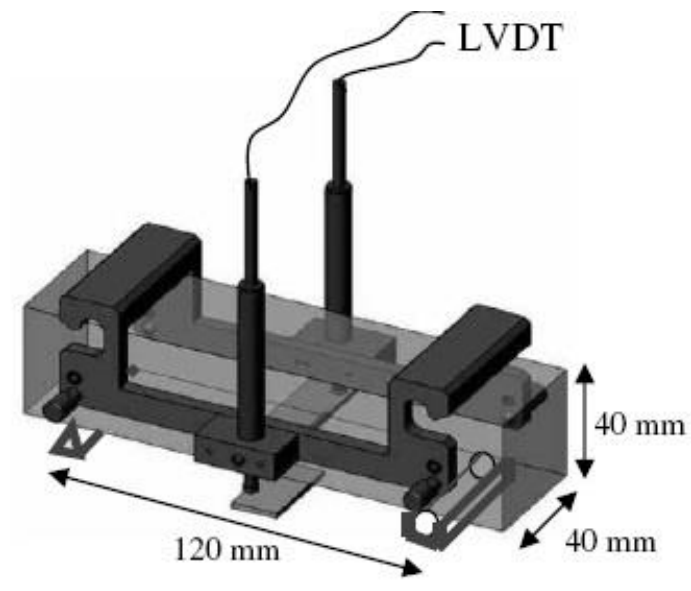

94

Figure 1: Four-point sample with measuring t.

96

97 The bending test results carried out on unreinforced mortar (MN) and fibre reinforced mortar (MNP) are

98 presented in figure 2 . The post peak residual load clearly highlights the role of fibres when samples are

99 not heated. The stress transfer between the faces of the cracks is significant and result is an increased

100 ductility. As already observed by other authors [12-14], this phenomenon attenuates very quickly between

101400 and $500^{\circ} \mathrm{C}$ and disappear beyond $500^{\circ} \mathrm{C}$. Figure 3 represents the evolution of the bending strength

102 with respect to the exposure temperature. The polypropylene fibres have a positive role until $400^{\circ} \mathrm{C}$ as it

103 was stated previously. The experimental values are reported in table 3. 

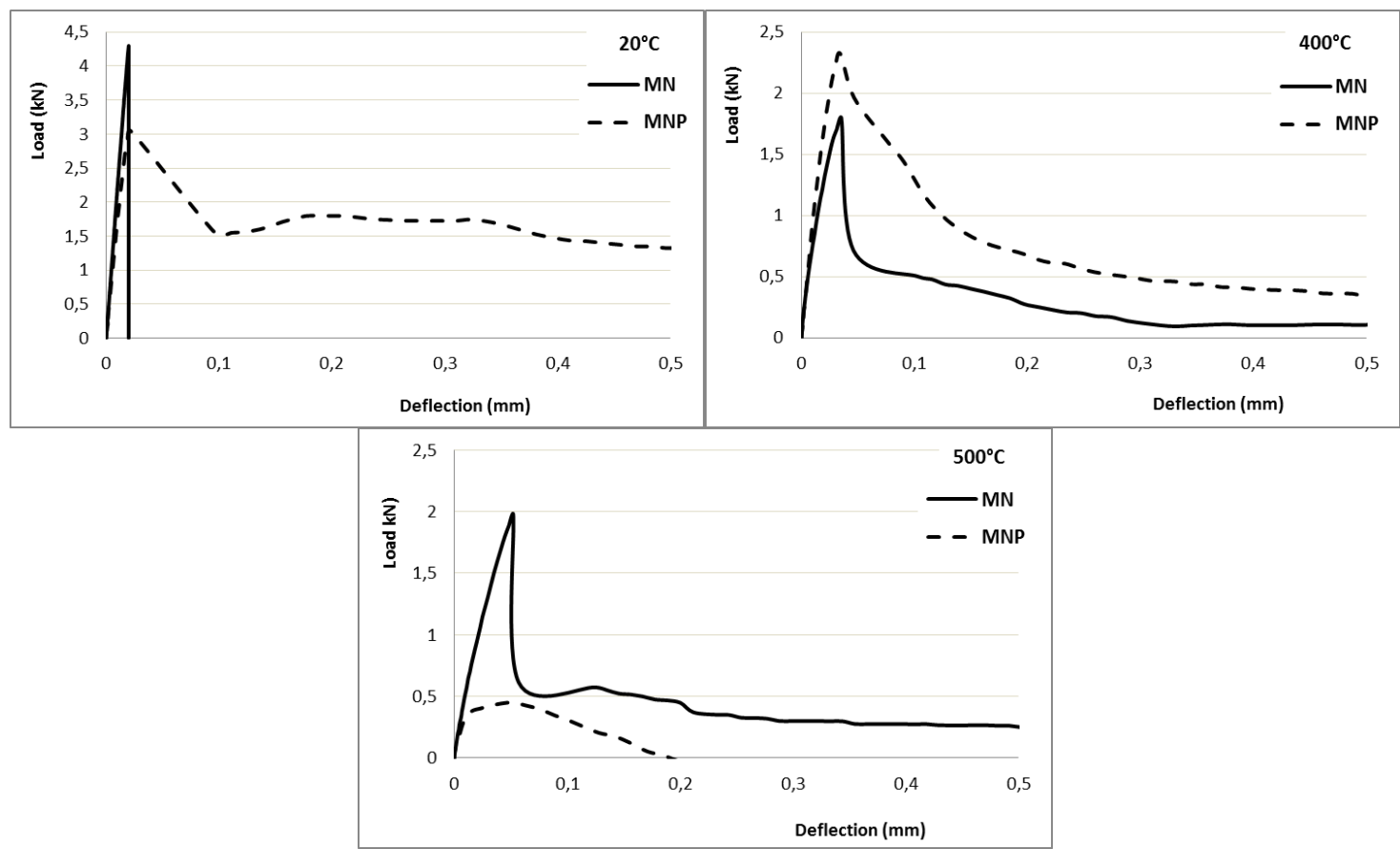

106 Figure 2: Representative curves of behaviour of the unreinforced mortar not (MN) and reinforced the $0.58 \%$ volume one of polypropylene fibres (MNP) in four-point bending test. 


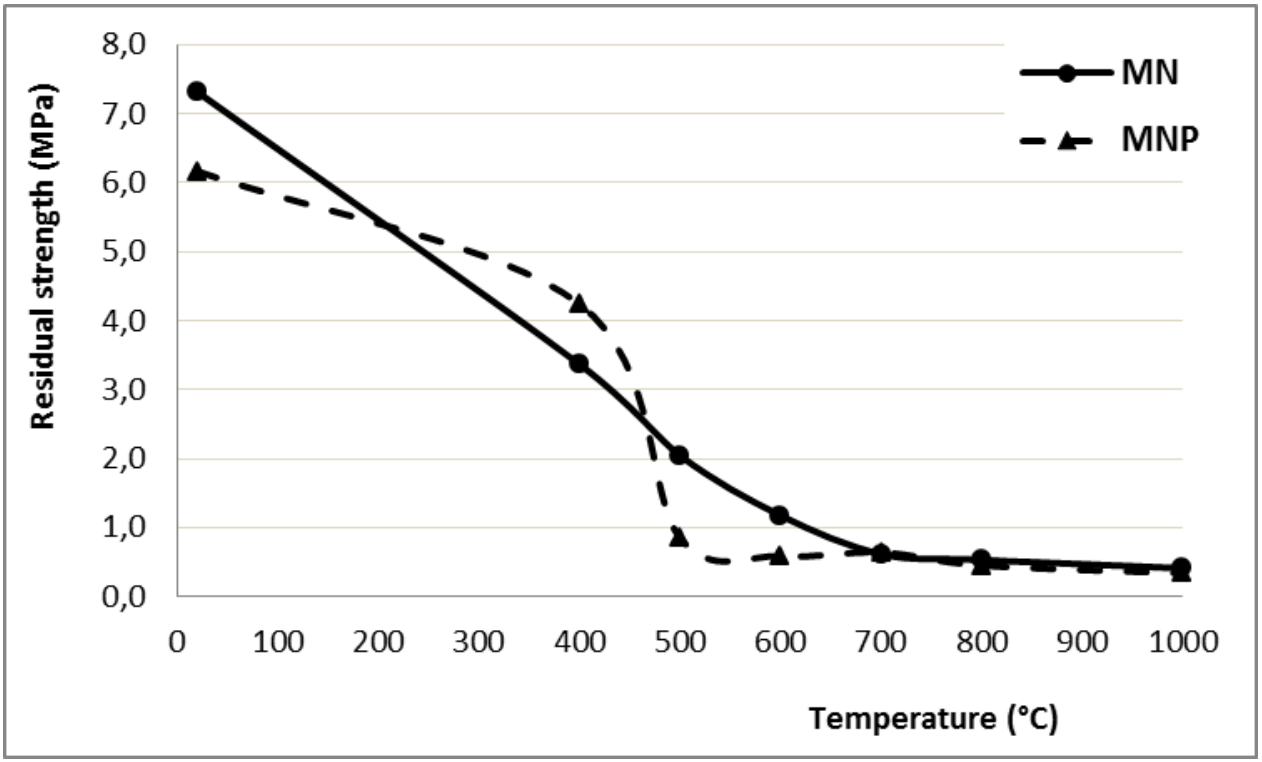

Figure 3: Evolution of the four-point bending tensile strengths of the mortars with respect to the exposure temperature (rate: $2^{\circ} \mathrm{C} / \mathrm{min}$ ).

Table 3: Evolution of the bending tensile stress (MPa) with temperature.

\begin{tabular}{|c|c|c|c|c|}
\hline Mortar & $\mathrm{T}^{\circ} \mathrm{C}$ & $20^{\circ} \mathrm{C}$ & $400^{\circ} \mathrm{C}$ & $500^{\circ} \mathrm{C}$ \\
\hline $\mathrm{MN}$ & & 7.3 & 3.4 & 2.0 \\
\hline MNP & & 6.2 & 4.2 & 0.8 \\
\hline
\end{tabular}

114 


\section{3.3. Young modulus}

117 Young modulus is defined as the elastic (and linear) stage of the load-deflection curve. The evolution of

118 the residual Young modulus with respect to the exposure temperature is shown in figure 4 and table 4 .

119 According to the test results, we notice that the modulus of the sample with fibre is greater than that of the

120 non-fibre samples. The variation is accentuated until $400^{\circ} \mathrm{C}$. At $500^{\circ} \mathrm{C}$; they are identical and beyond this

121 temperature; the young modulus of the fibred samples becomes almost zero.

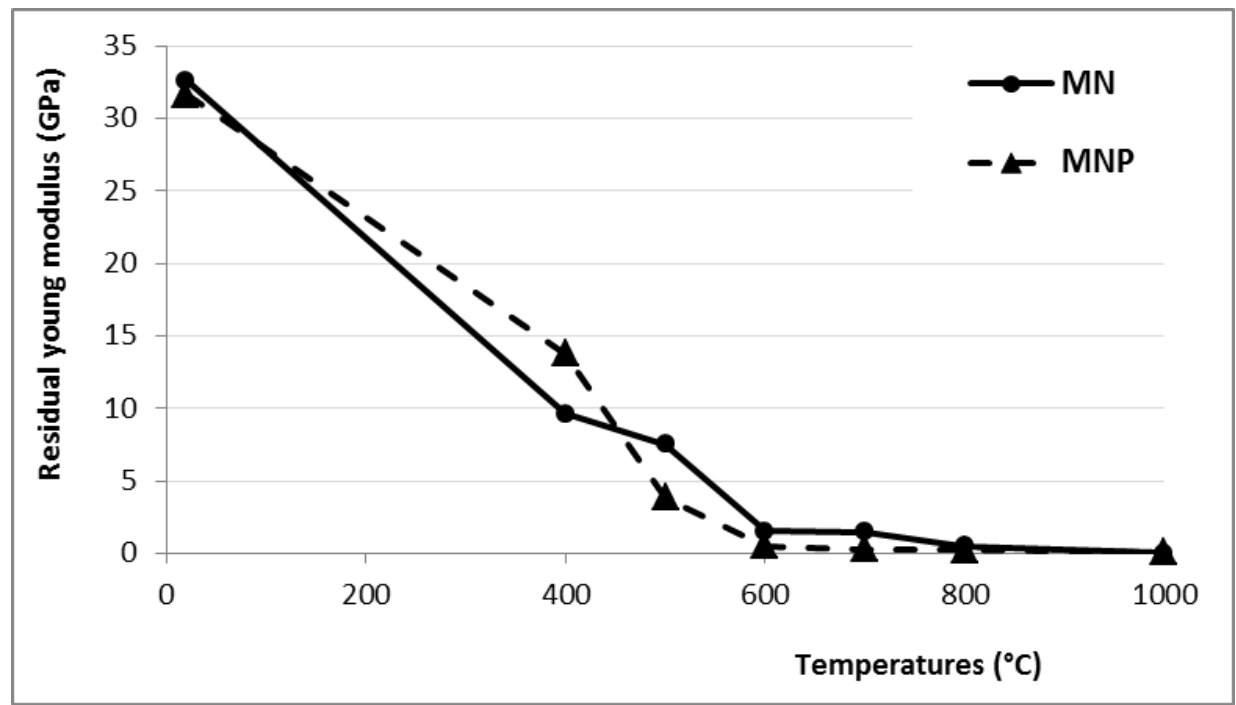

123 Figure 4: Residual Young modulus (four-point bending test) vs. temperature of the heat treatment

124

Table 4: Young modulus (GPa) vs. temperature.

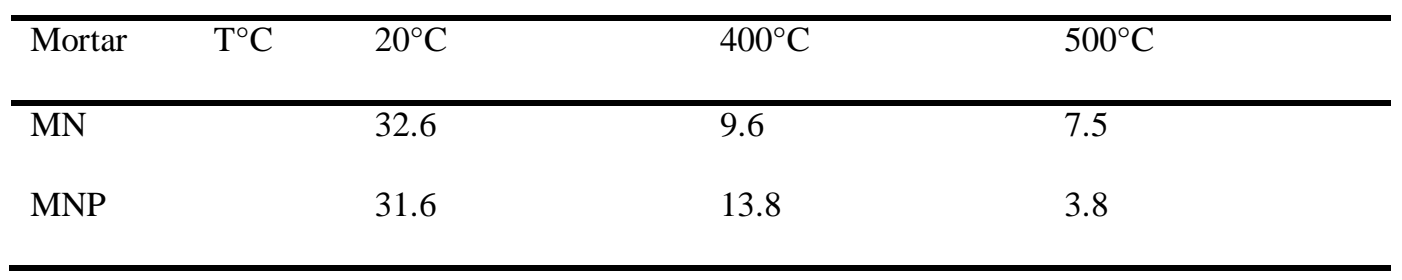


129 The fracture energy is defined as the area under the stress-strain curve of the four-point bending test [15].

130 Figure 5 and table 5 show the test results of the fracture energy with respect to the exposure temperature.

131 When the samples are not heated, the fracture energy of the fibre specimen is about three times the energy

132 of the non-fibre sample. This difference in fracture energy tends to converge and nullify at about $500^{\circ} \mathrm{C}$.

133 Above $500^{\circ} \mathrm{C}$, gain increase in fracture energy decreases for samples with fibres.

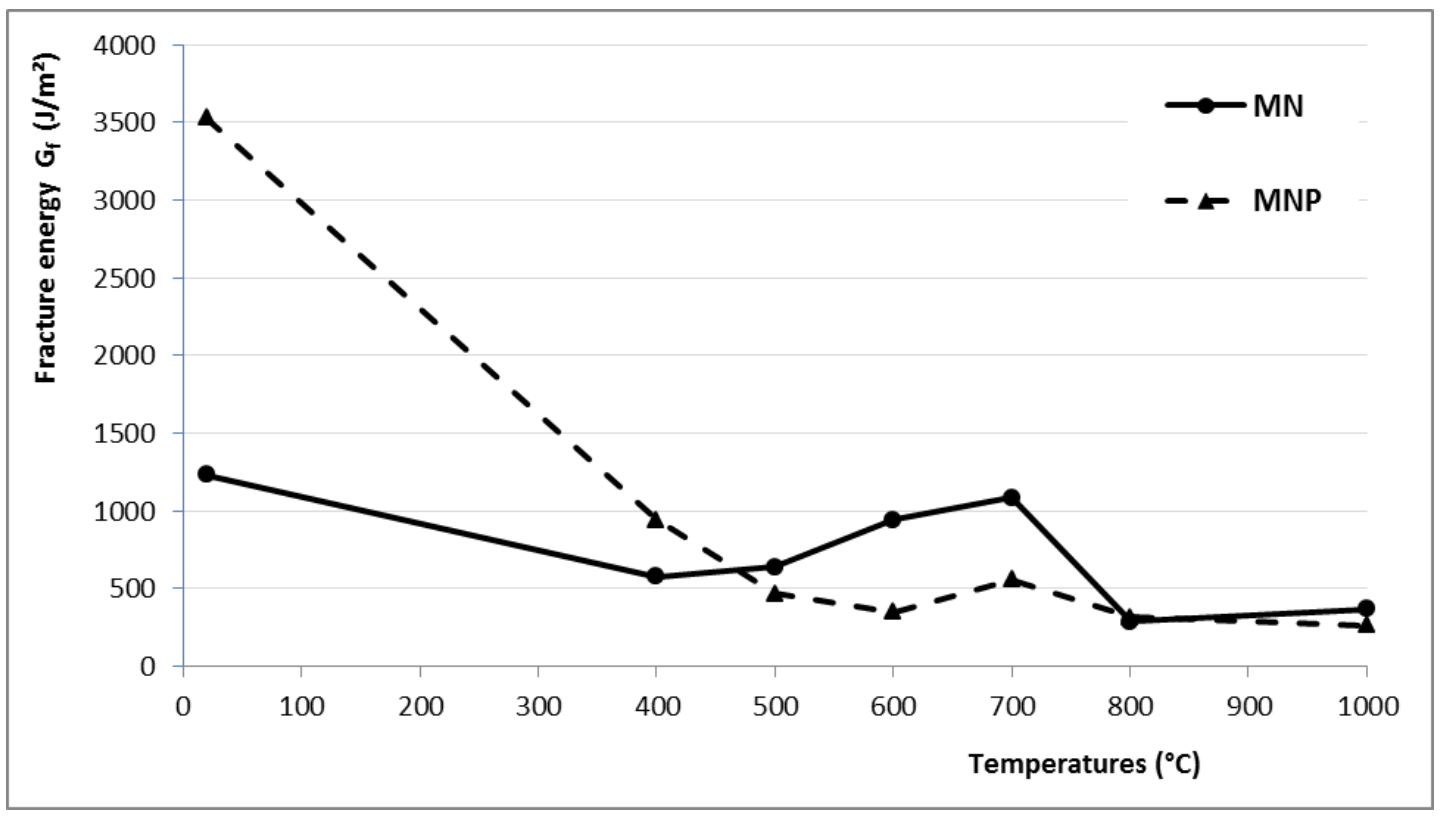

Figure 5: Evolution of the fracture energy with respect to the exposure temperature.

Table 5: Evolution of the fracture energy $\mathrm{G}_{\mathrm{f}}\left(\mathrm{J} / \mathrm{m}^{2}\right)$ with respect to the exposure temperature.

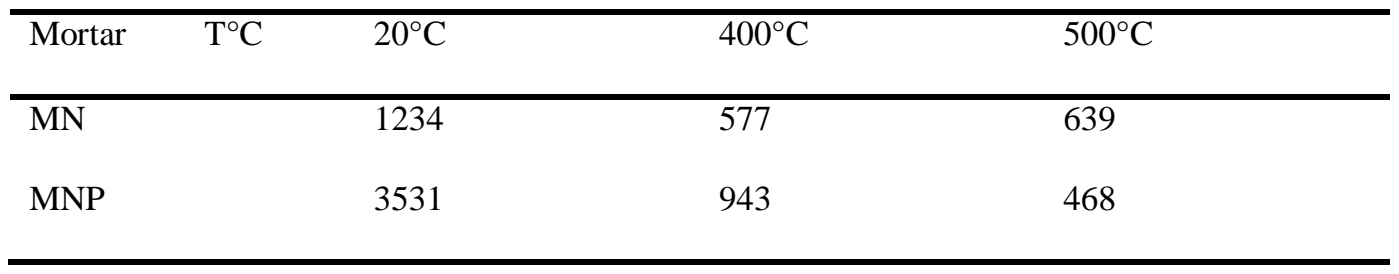




\section{$138 \quad 3.5$. Stress intensity factor}

139 The stress intensity factor $\mathrm{K}_{\mathrm{I}}$ characterizes the resistance of material to the propagation of the crack and to

140 the damage [16-18]. This parameter can be deducted from the calculation of the fracture energy $\mathrm{G}_{\mathrm{f}}$ and of

141 the Young modulus E. It is defined by the following relation:

$142 \quad \mathrm{~K}_{\mathrm{I}}=\left(\mathrm{G}_{\mathrm{f}} \cdot \mathrm{E}\right)^{0.5}$

143 This parameter takes into account the degradation of the cement matrix; rather quantifiable by the young

144 modulus and the fibre degradation (modification of the characteristics of fibres, loss of cohesion), rather

145 quantifiable by the fracture energy. This is thus a representative parameter of the overall damage of the

146 fibrous material.

147 The evolutions of the stress intensity factor of the mortars with respect to the exposure temperature are

148 illustrated in figure 6 and table 6.

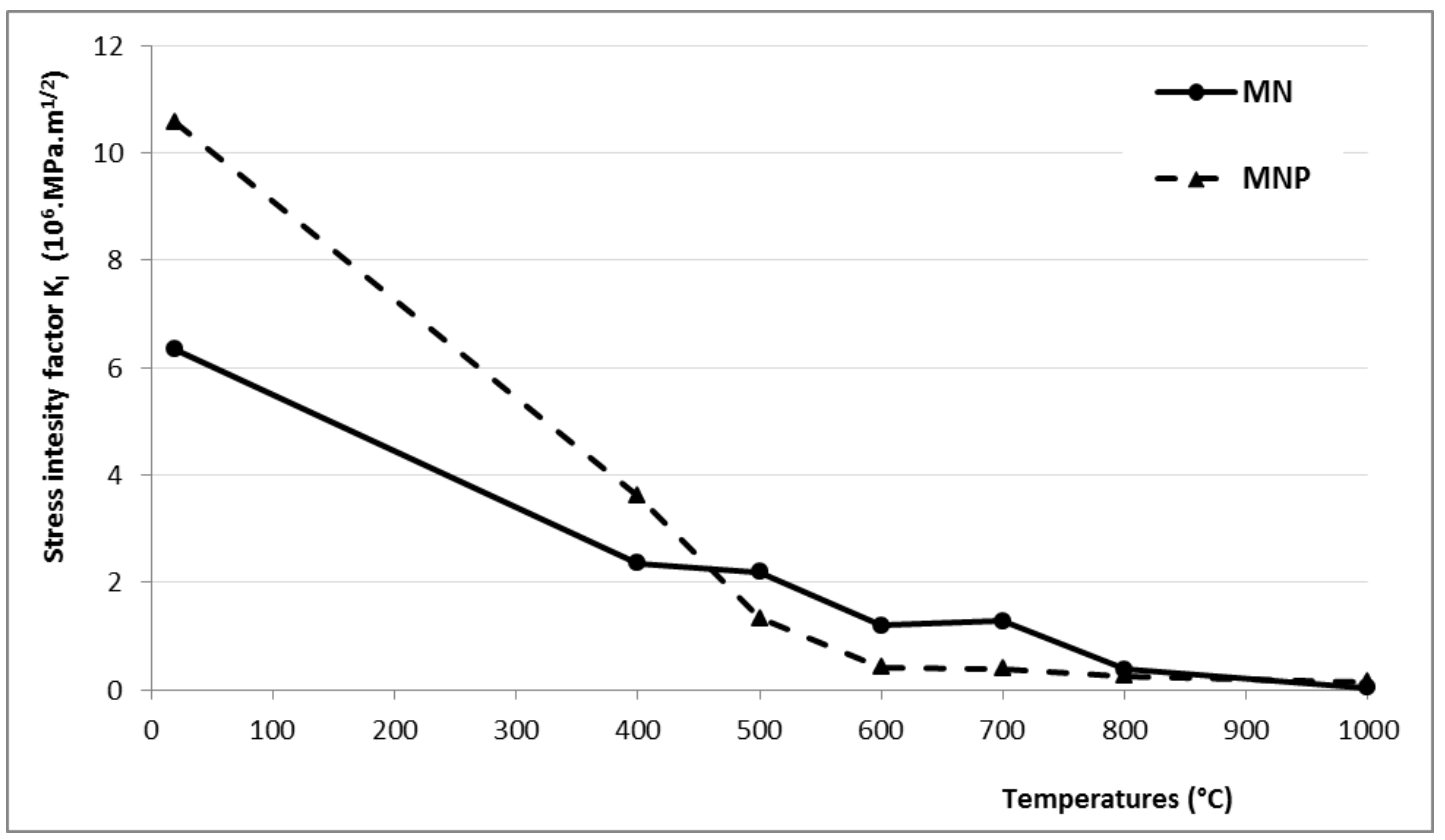

$150 \quad$ Figure 6: Evolution of the stress intensity factor $\mathrm{K}_{\mathrm{I}}$ with respect to the exposure temperature. 
151 Table 6: Evolution of the intensity factor $\mathrm{K}_{\mathrm{I}}\left(10^{6} \mathrm{MPa} \cdot \mathrm{m}^{1 / 2}\right)$ with respect to the exposure temperature.

\begin{tabular}{|c|c|c|c|}
\hline Mortar $\quad \mathrm{T}^{\circ} \mathrm{C}$ & $20^{\circ} \mathrm{C}$ & $400^{\circ} \mathrm{C}$ & $500^{\circ} \mathrm{C}$ \\
\hline MN & 6,3 & 2,4 & 2,2 \\
\hline MNP & 10,6 & 3,6 & 1,3 \\
\hline
\end{tabular}

152

153 According to the test results (figure 5 and figure 6), we notice that the fracture energy and the stress

154 intensity factor have similar behaviour when exposed to equivalent temperatures.

155 The stress intensity factor for the fibre mortar $\mathrm{K}_{\mathrm{I}}$ has a great value at $20^{\circ} \mathrm{C}$ and $400^{\circ} \mathrm{C}$. Beyond this limit,

156 we observe a very pronounced decreasing of the stress intensity factor. This decrease is mainly due to the 157 fact that the polypropylene fibres have certainly totally melted and calcined. The fibres that stop crack 158 propagation are no longer present.

159 At the high temperatures, two types of damage appear: (1) the physicochemical modifications and (2) 160 cracking of the cementing matrix $[11,19,20]$. Results from a previous study showed that the 161 polypropylene fibres had more effect on the reduction of cracking than on the reduction of the 162 physicochemical modifications [21]. From $170^{\circ} \mathrm{C}$, the polypropylene fibres melt and create a connected 163 porosity [22]. This porosity allows evacuating vapour over-pressures and thus reducing cracking [23].

164 This weaker cracking explains the best results in term of resistance, ductility and fracture energy or stress 165 intensity factor.

166 Moreover, when the temperature of the furnace is $400^{\circ} \mathrm{C}$, the temperature inside the specimen is lower 167 and can be not sufficient to destroy all fibres. The propagation of heat is slowed down in the dehydrated 168 cementing matrix [11-17]. The fibres disappear gradually from the periphery of the sample towards the 169 centre: the kinetics of propagation of heat is slowed down by the more or less insulating dehydrated 170 cementing matrix [8]. Fibres remain in the heart of the sample and contribute to the ductility of material. 171 Beyond $500^{\circ} \mathrm{C}$, the fibres completely disappeared to create an additional porosity [22-26]. This porosity 
172 leads thus to a lower energy than that of the not fibred samples. This process has been observed by optical

173 microscopy (figure 7). Small slice extracted from different depth of a sample exhibits completely calcined

174 polypropylene fibres in the first millimetres. Deeper slice contains yet partially melted fibre.

175

176

177

178

179

180

181

182

183

184

185

186

187

188

189

190

191

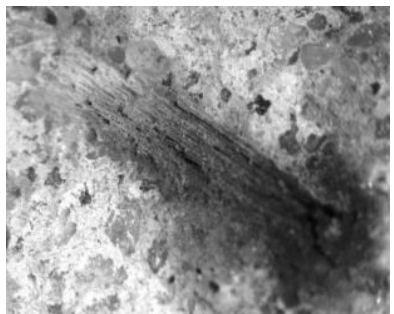

(a)

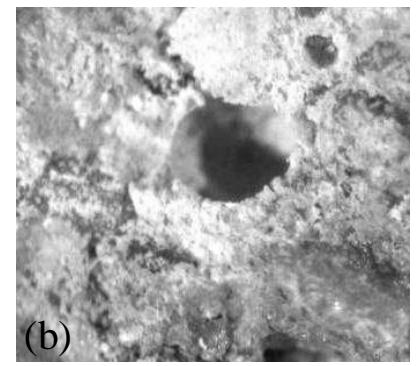

(b)

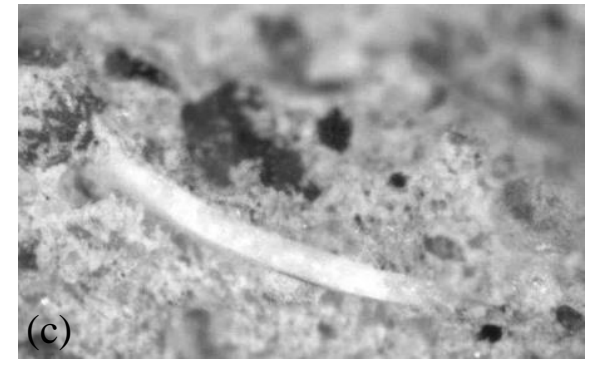

Figure 7 : Optical microscopy observations. (a) Calcined fibre. (b) Melted Fibre. (c) Partially melted fibre.

\section{FLAME TEST}

\subsection{Exposure to fire}

The second heat treatment consists of placing plates of dimensions $16 \times 16 \times 4 \mathrm{~cm}^{3}$ made of unreinforced mortar and polypropylene fibre reinforced mortar in a flame test apparatus (figure 8a). Five thermocouples were inserted in the plate (figure $8 b$ ) at different depth and two other thermocouples were positioned in contact with the internal face (hot face) and external face (cold face) (figure 8c). The temperature of the exposed face (dimensions $16 \times 16 \mathrm{~cm}^{2}$ ) is forced to $1000^{\circ} \mathrm{C}$ and was maintained for one hour. Figure 9 compares the rate of temperature between the experimental curve and the ISO 834 standard fire. The experimental rate of temperature is similar to that of ISO 834 up to $1000^{\circ} \mathrm{C}$. This rate leads to a strong temperature gradient in the sample. The sample dimensions are assumed to be enough to observe spalling.

The heat flux is assumed to be unidirectional. The flame position allows setting in a precise manner the temperature of the surface. 

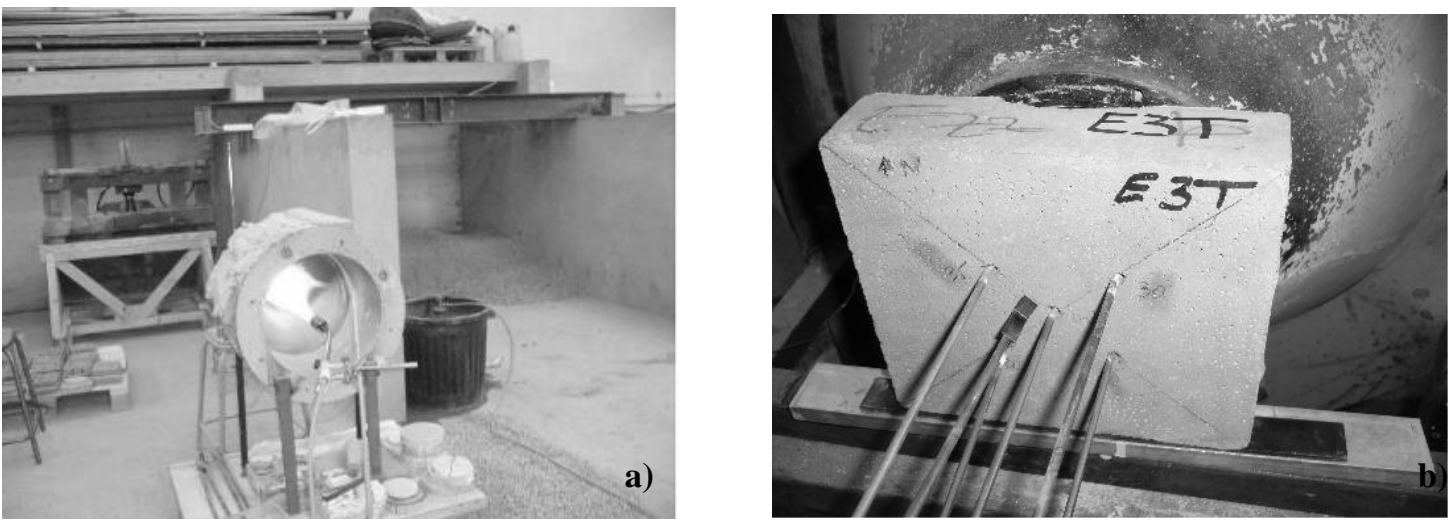

\section{Plate}

$\left(16 \times 16 \times 4 \mathrm{~cm}^{3}\right)$

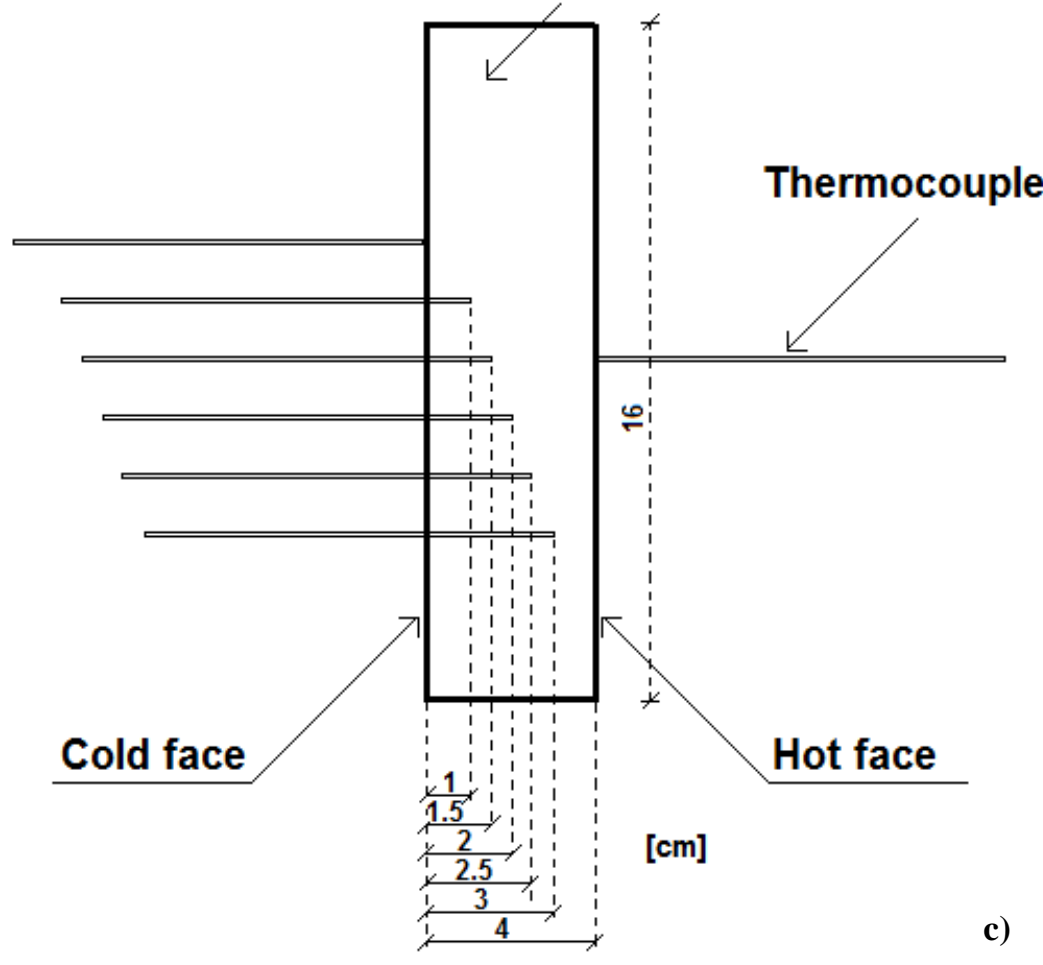

Figure 8: a) mounting flame test, b) drilled external face, 
196 Two series of test were performed:

197 - First series (equipped with 7 thermocouples (type K)): the evolution of the temperature of this series is

198 obtained by placing thermocouples (drilled after casting) at different depths of the sample (external face -

$1991 \mathrm{~cm}-1.5 \mathrm{~cm}-2 \mathrm{~cm}-2.5 \mathrm{~cm}-3 \mathrm{~cm}$, and the internal side) as illustrated in figure 8c.

200 - Second series (equipped with 2 thermocouples): thermocouples were positioned in contact with the

201 external (cold face) side and at the internal (hot face) side. It has to be noted that this thermocouple

202 measures radiation and convection from the flame, rather than surface temperature at the exposed face.

203 However it was very difficult to achieve the measuring of the surface real temperature.

204 At the end of the test, cooling was performed naturally at room temperature. Punching shear tests were,

205 then carried out for a comparison.

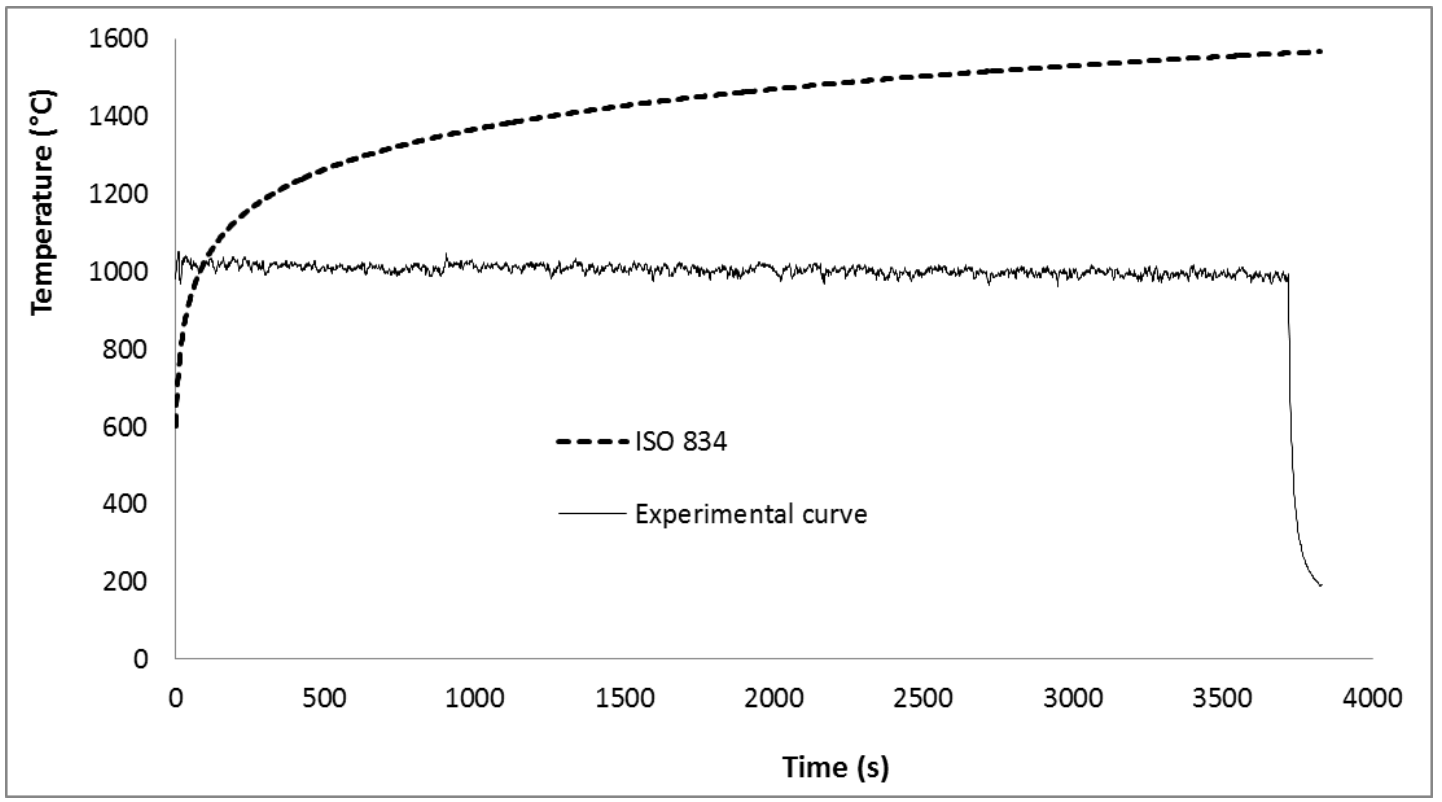

Figure 9: Comparison between ISO 834 fire and the experimental curve. 


\section{4.2. Heat transfer}

211 During these tests, and after 5 minutes of treatment, we observed, drops of water and water vapour 212 escaping from the drilling of thermocouples of the unexposed surface of the test sample for the 2 types of 213 mortars. Nine minutes after treatment, we observed the apparition of a fist crack in the standard mortar.

214 This crack has developed from lateral side to the centre. However, this phenomenon did not appear for 215 fibre reinforced mortar.

216 Figure 10 shows the evolution of the temperature of both mortars with respect of time and depth. The

217 temperature evolution consists of three stages: a rapid increase of the temperature until $100^{\circ} \mathrm{C}$, an 218 isothermal stage around $100^{\circ} \mathrm{C}$ and an increase of the temperature. The isothermal stage around $100^{\circ} \mathrm{C}$ 219 corresponds to the evaporation of free water at different depths. Mindeguia et al., [8] observed this 220 plateau at $100^{\circ} \mathrm{C}$ for low compactness concrete. 


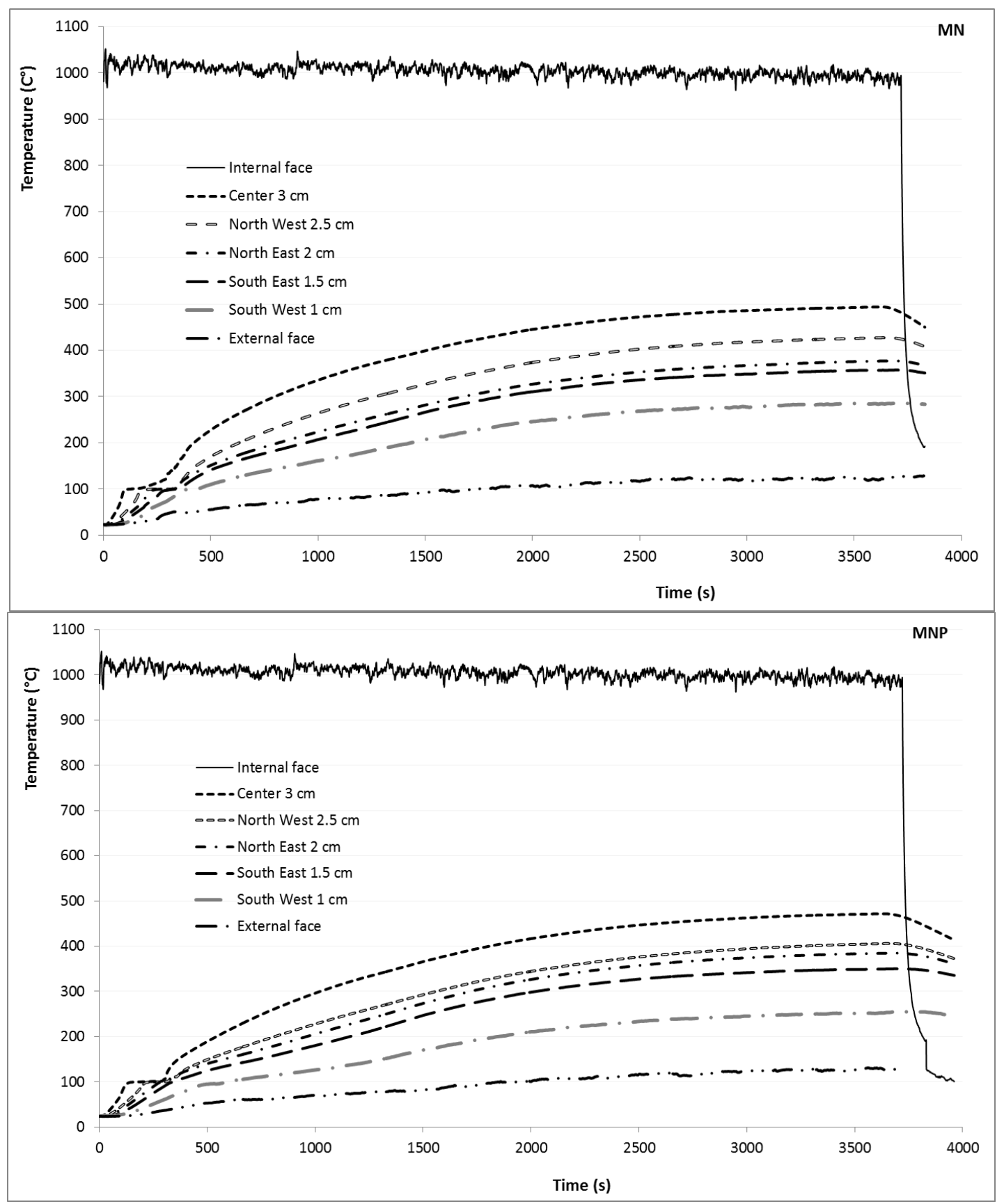

223 Figure 10: Evolution of the temperature at different depths of the non-fibre mortar and fibre mortar. 
225 It is this possible to quantity the heat propagation in the two mortars using the temperature measured by 226 thermocouples. To check the effect of drilling on this transfer, plates were tested without drillings 227 (without thermocouple), and only hot face temperature and cold side temperature were measured. It was 228 seen that the temperature at the external face is similar for plates with and without drilling. Temperature gradients in plates made of standard mortar and fibre reinforced mortar are shown in figure 11. The

230 presence of polypropylene fibres does not lead to significant changes in the phenomenon of heat 231 propagation. The temperature at $3 \mathrm{~cm}$ depth (i.e at $1 \mathrm{~cm}$ of the hot face) does not exceed $500^{\circ} \mathrm{C}$. In the 232 outer face (i.e. at $4 \mathrm{~cm}$ from the hot face), the temperature reaches approximately $140^{\circ} \mathrm{C}$ after one hour of 233 exposure.

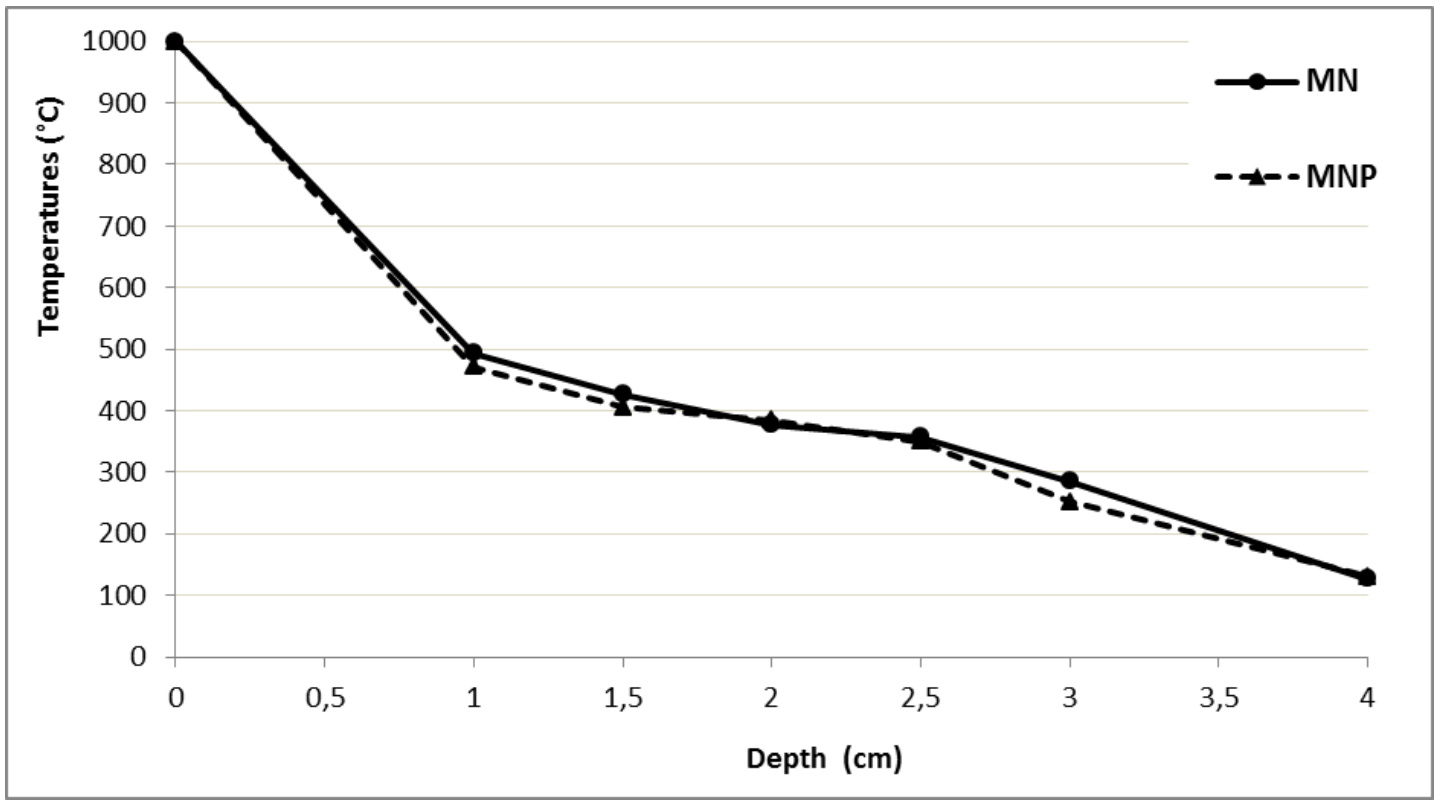

Figure 11: Thermal gradient within test specimens after one hour of thermal exposure during flame tests. 


\subsection{Mass loss after tests}

241 The mass loss at the end of the test is almost identical for the two mortars. The mass loss of the standard

242 mortar (MN) and fibre mortar (MNP) is $6.4 \%$ and $6.5 \%$ respectively. We can say that the fibres

243 embedded in the mortar have virtually no influence on the evaporation of water from mortar and

244 hydroxides $\mathrm{OH}$ after this heating. Similar observations were reported by [27].

\section{4.4. Residual strength}

246 Subsequently, to enable a comparison between the residual mechanical strength of samples a punching

247 shear strength [28] test was performed on non-drilled samples as presented in figure 12. Results are

248 reported on table 7. Each value is the mean between ten samples; the difference between these ten values

249 is maximum 3\%. Before flame exposure, punching shear strengths are quite similar for the two mortars.

250 After flame exposure, all mortars show a loss of punching shear strength. Fibre mortars have a lower

251 residual strength compared to those without fibres: strength reduction is $64.5 \%$ for mortar without fibre

252 and $73.7 \%$ for mortar with polypropylene fibres. A temperature of $1000^{\circ} \mathrm{C}$ at the hot face for 1 hour

253 conducts to temperature greater than $170^{\circ} \mathrm{C}$ (polypropylene melting) up to about $1 \mathrm{~cm}$ from the cold face:

254 it can be considered that all fibres were completely melted up to about $1 \mathrm{~cm}$ from the cold face. The

255 induced porosity due to the degradation of the fibres decreases the strength. However, after heating, a part

256 of polypropylene fibres is still present in the outer face side. The cold face temperature is only $140^{\circ} \mathrm{C}$

257 after one hour, while the melting point is given at $170^{\circ} \mathrm{C}$. Thus, the strength loss is limited. These results

258 are consistent with the results obtained in a preliminary study [29]. 

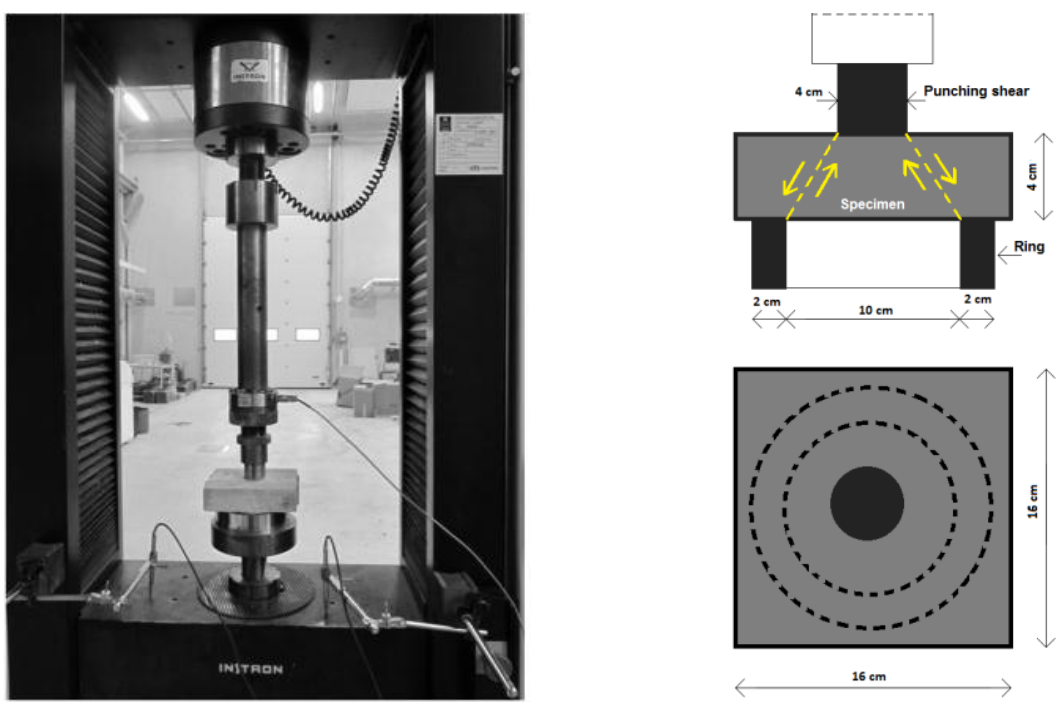

Figure 12: Test bed to punching shear.

261

\begin{tabular}{ccc}
\hline & Non-heated & Heated \\
Mortars & $\mathrm{F}_{\max }(\mathrm{kN})$ & $\mathrm{F}_{\max }(\mathrm{kN})$ \\
\hline Non-fibre & 20.3 & 7.2 \\
Fibre & 20.9 & 5.5 \\
\hline
\end{tabular}

Table 7: Residual punching shear effort of the plates after testing at flame.

264 4.5. Spalling during heating

265 Induced porosity due to melting of polypropylene fibres is considered to facilitate the transfer of steam

266 and avoid spalling [23, 30, 31]. It is reasonable to consider that concrete incorporating polypropylene

267 fibre can provide a benefit to concrete so as to prevent it from explosive spalling, due to the fact that it is

268 melted under temperature around $170^{\circ} \mathrm{C}$ and hence accumulated moisture pressure in concrete can escape through inter-connected pores to outside of concrete. Samples from mortars with and without fibre at a 
271 mortars with the same fibre volume ratio but a water/cement ratio of 0.4 spalled during testing (figure 13).

272 Similar observations were conducted in studies on concrete with low water/cement ratio (concrete with

2730.26 water/cement ratio and $1 \mathrm{~kg} / \mathrm{m}^{3}$ of polypropylene fibres spalled, but concrete with 0.26 water/cement

274 ratio and $0.6 \mathrm{~kg} / \mathrm{m}^{3}$ of polypropylene fibres and $40 \mathrm{~kg} / \mathrm{m}^{3}$ of steel fibres did not spall [32]) or on

275 lightweight concrete (concrete with 0.33 ratio spalled, and concrete with 0.42 ratio did not spall [5]).

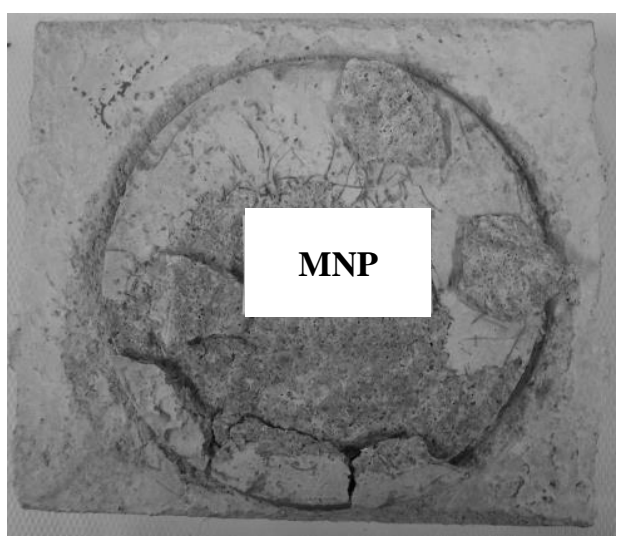

Figure 13: Example of spalling of sample made with $0.58 \%$ polypropylene fibre and $w / c=0.4$.

\section{CONCLUSION}

280 This study highlights the contribution of polypropylene fibres in cement based building materials exposed

281 to an increasing temperature or exposed to flame. We have studied the mechanical behaviour of standard

282 mortars and fibre reinforced mortars heat-treated at $400^{\circ} \mathrm{C}, 500^{\circ} \mathrm{C}, 600^{\circ} \mathrm{C}, 700^{\circ} \mathrm{C}, 800^{\circ} \mathrm{C}$ and $1000^{\circ} \mathrm{C}$.

283 Two types of treatment have been made: a heating furnace (low rate) and an extreme heated test with 284 flame (high rate). 
285 At room temperature (before heating), the post peak stress clearly highlights the role of the fibres: the

286 stress transfer between the faces of the cracks by polypropylene fibres is important and gives samples 287 ductility.

288 After heating, below $400^{\circ} \mathrm{C}$, the fibres have an uncracking effect by allowing the dissipation of fluid over 289 pressure in the matrix. This phenomenon disappears at a temperature over $500^{\circ} \mathrm{C}$. The fibre samples have 290 greater young modulus compared to that of the non-fibred ones with an increasing gap until a temperature 291 of $400^{\circ} \mathrm{C}$ and decreases beyond this value. At $500^{\circ} \mathrm{C}$, they are identical. After $500^{\circ} \mathrm{C}$, the young modulus 292 becomes almost zero. The fracture energy at $20^{\circ} \mathrm{C}$ is 3 times greater for the fibred samples compared to 293 the non-fibred ones. This ratio drops to 1.5 at $400^{\circ} \mathrm{C}$. Fibres effects are negative beyond the temperature 294 of $500^{\circ} \mathrm{C}$.

295 It appears, from the flame test that the fibre mortar and non-fibre mortar have the same thermal 296 behaviour. After one hour, the unexposed side is about $140^{\circ} \mathrm{C}$.

297 For the residual punching strength; the results show that polypropylene fibres are not so efficient: the 298 polypropylene fibres limit the cracking during heating but do not increase the punching strength.

299 By melting at $200^{\circ} \mathrm{C}$ the polypropylene fibres are considered to create a porosity which allows a 300 limitation of the pressure due to the evaporation of water treatment and thus a limitation of cracking. The 301 spalling phenomenon was not observed for all mortars having a water/cement ratio of 0.5. However, 302 spalling was observed for mortars with water/cement ratio of 0.4 .

303 For design of concrete structures, it has to be noted that the temperature remains below $500^{\circ} \mathrm{C}$ after two 304 centimetres inside the concrete (i.e. after the cover over reinforcing steel). Up to $500^{\circ} \mathrm{C}$, polypropylene 305 reinforced mortar gives a pseudo-ductile behaviour with a better strength, a better Young modulus, a 306 better fracture energy than mortar without fibre. Thus, the safety of concrete structures submitted to fire is 307 increased. After fire, the rehabilitation of concrete cover will be limited and associated cost decreased. 


\section{References}

309 [1] M. Grzybowski, S.P. Shah, Shrinkage cracking of fiber reinforced concrete. ACI Materials Journal, 87 $310 \quad$ (1990) 138-148.

311 [2] C.D. Johnston, Proportioning, mixing and placement of fibre-reinforced cements and concretes,

312 Production Methods and Workability of Concrete. Proceedings of the international RILEM conference,

313 edited by Bartos, Marrs and Cleland, E\&FN Spon, London, (1996) 155-179.

314 [3] T.T. Lie, V.K.R. Kodur, Thermal and mechanical properties of previous steel fibre-reinforced

315 concrete at elevated temperature, Canadian Journal of Civil Engineering. 232 (1996) 511-517.

316 [4] A. Serdar, Y. Halit, B. Bülent, High temperature resistance of normal strength and autoclaved high

317 strength mortars incorporated polypropylene and steel fibres, Construction and Building Materials. 22

$318 \quad$ (2008) 504-512.

319 [5] A. Bilodeau, V.K.R. Kodur, G.C. Hoff, Optimization of the type and amount of polypropylene fibres

320 for preventing the spalling of lightweight concrete subjected to hydrocarbon fire, Cement and Concrete

321 Composites. 26 (2004) 163-174.

322 [6] A. Nishida, N. Yamazaki, H. Inoue, U. Schneider, U, Diederichs, Study on the properties of high

323 strength concrete with short polypropylene fibre for spalling resistance, Concrete under severe conditions:

324 environment and loading. 2 (1995) 1141-1150.

325 [7] M. Colombo, R. Felecitti, New NDT for techniques for the assessment of fire-damaged concrete 326 structures, Fire Safety.42 (2007) 461-472.

327 [8] J-C Mindeguia, P. Pimienta, A. Noumowè, M. Kanema, Temperature, pore pressure and mass

328 variation of concrete subjected to high temperature - Experimental and numerical discussion on spalling

329 risk, Cement and Concrete Research. 40 (2010) 477-487.

330 [9] D.J. Hannant, Fibre cement and fibre concrete. UK: John Wiley \& Sons, (1978) 238. 
331 [10] C. Andrade, J. Sarría, C. Alonso, Relative humidity in the interior of concrete exposed to natural and 332 artificial weathering, Cement and Concrete Research. 29 (1999) 1249-1259

333 [11] B. Georgali, P.E. Tsakiridis, Microstructure of fire-damaged concrete, A case study, Cement and 334 Concrete Composites. 27 (2005) 255-259.

335 [12] P. Pliya, A.I. Beaucourt, A. Noumowé, Influence des fibres de polypropylène sur le comportement 336 de bétons soumis à une température élevée. Colloque International sur la caractérisation et modélisation 337 des matériaux et structures, Tizi-Ouzou, Algeria, 2008.

338 [13] J. Xiao, H. Falkner, On residual strength of high-performance concrete with and without 339 polypropylene fibres at elevated temperatures, Fire Safety Journal 41 (2006) 115-121.

340 [14] A. Behnood, M. Ghandehari, Comparison of compressive and splitting tensile strength of high341 strength concrete with and without polypropylene fibres heated to high temperatures, Fire Safety Journal $34244(2009)$ 1015-1022.

343 [15] X.H. Guo, F. Tin-Loi, H. Li, Determination of quasibrittle fracture law for cohesive crack models,

344 Cement and Concrete Research. 29 (1999) 1055-1059.

345 [16] J.C. Charmet, Mécanique du solide et des matériaux: Elasticité-Plasticité-Rupture, ESPCI, 2012, pp.

346 113-144. http://www.pmmh.espci.fr/fr/Enseignement/Archives/MecaSol/Cours_Mecasol_0.pdf (accessed 34710 June 2013).

348 [17] A. Menou, G. Mounajed, H. Boussa, A. Pineaud, H. Carre, Residual fracture energy of cement paste, 349 mortar and concrete subject to high temperature, Theoretical and Applied Fracture Mechanics. 45 (2006) $350 \quad 64-71$.

351 [18] P. Pierre, R. Pleau, M. Pigeon, A finite element study of the influence of micro-fibres on the tensile 352 strength of cement paste, Proceeding of the 3rd International RILEM Workshop: High performance Fibre 353 reinforced Cement Composites 3 (HPFRC 3), ed. A.E., Naamann and H.W. Reinhardt. Mainz, Germany, $354 \quad 1999$. 
355 [19] Y.F. Fu, Y.L. Wong, C.S. Poon, C.A. Tang, P. Lin, Experimental study of micro/macro crack

356 development and stress-strain relations of cement-based composite materials at elevated temperatures,

357 Cement and Concrete Research. 33 (2004) 789-797.

358 [20] H. Fares, A. Noumowé, S. Remond, Self-consolidating concrete subjected to high temperature,

359 Cement and Concrete Research 39 (2009) 1230-1238.

360 [21] M. Ezziane, L. Molez, R. Jauberthie, D. Rangeard, Heat exposure tests on various types of fibre

361 mortar, European journal of environmental and civil engineering. 15 (2011) 715-726.

362 [22] J. Komonen, V. Penttala, Effect of high temperature on the pore structure and strength of plain and 363 polypropylene fibre reinforced cement pastes, Fire Technology. 39 (2003) 23-34.

364 [23] P. Kalifa, G. Chéné, C. Gallé, High-temperature behaviour of HPC with polypropylene fibres from 365 spalling, Cement and Concrete Reseach. 31 (2001) 1487-1499.

366 [24] A. Noumowé, P. Clastres, G. Debicki, J.L. Costaz, Transit heating effect on high strength concrete,

367 Nuclear Engineering and Design. 166 (1996) 99-108.

368 [25] I. Hager, T. Tracz, Residual transport properties of heated HPC modified with polypropylene fibres,

369 1st International Workshop on Concrete Spalling due to Fire Exposure. Proceedings, F. Dehn, E.A.B.

$370 \quad$ Koenders. (2005) 221-228.

371 [26] L. Min, Q.C. Xiang, S.Wei, Mechanical properties of high-strength concrete after fire, Cement and 372 Concrete Research. 34 (2004) 1001-1005.

373 [27] P. Pliya, A.L. Beaucour, A. Noumowe, A way to improve the behaviour of concrete at high 374 temperature: addition of a cocktail of polypropylene and steel fibres, 3rd International FIB Annual 375 Convention \& Bridge conference. Washington-DC, 2010.

376 [28] P.h. Menétrey, Synthesis of punching failure in reinforced concrete, Cement and Concrete Research. 24 (2002) 497-507. 
378 [29] M. Ezziane, T. Kadri, R. Jauberthie, L. Molez, Evolution of the punching strength of mortar 379 subjected to fire, MATEC Web of Conferences, IInd International Seminar INVACO - Innovation \& 380 Valorization in Civil Engineering \& Construction Materials. 2 (2012).

381 [30] CEN TC 250, Eurocode, Design of concrete structures. Part 1-2: General rules. Structural fire design. 382 (2004).

383 [31] G.A. Khoury, B. Willoughby, Polypropylene fibres in heated concrete. Part 1: molecular structure 384 and materials behaviour. Magazine of Concrete Research. 60 (2008) 125-136.

385 [32] G-F. Peng, W-W Yang, J. Zhao, Y-F. Liu, S-H. Bian, L-H. Zhao, Explosive spalling and residual 386 mechanical properties of fibre-toughened high-performance concrete subjected to high temperatures, 387 Cement and Concrete Research.36 (2006) 723-727. 